\title{
KEWIRAUSAHAAN TAHU ISI LELE (TISeL)
}

\author{
Denni Denni, Buntukaraeng Buntukaraeng
}

\begin{abstract}
Abstrak
Makanan Tahu isi adalah lauk pauk yang umum dikonsumsi di Indonesia sebagai cemilan atau jadi lauk pauk Bersama nasi putih. Namun ketika tahu isi ini dimodifikasi dengan isinya diganti dengan daging ikan lele tentunya mengubah cita rasnya. Selama ini dikenal dengan tahu isi yang berisi sayuran, dan tauge serta cabe. Olahan kedelai ini bernilai gizi yang baik. Hasil uji organoleptik tahu isi Lele atau disingkat TISel memberikan penilaian suka untuk cita rasa, warna, aroma, dan tekstur. Dengan demikian, tahu isi ini dapat dipasarkan ke masyarakat karena memiliki nilai jual yang sesuai dengan ketertarikan konsumen. Harganya juga terjangkau yaitu dua ribu rupiah.
\end{abstract}

Kata-kata kunci: inovasi, tahu isi, ikan lele, kewirausahaan.

\section{PENDAHULUAN}

Dizaman sekarang ini kalau kita melihat realita yang terjadi khususnya di dunia usaha, banyak orang yang berlomba-lomba untuk menciptakan sebuah usaha-usaha untuk dapat memenuhi kebutuhan setiap orang baik itu pelanggan maupun sebagai pengusaha dengan inovasi yang baru. Banyak sekali usaha yang bisa kita ciptakan di zaman milenial ini, namun penulis tertarik untuk memulai dengan usaha tahu isi ikan lele.

Yang mendasari penulis tertarik untuk memulai usaha ini adalah Yang pertama adalah belum ada orang yang memulai usaha ini dengan menu "Tahu Isi Ikan Lele" sekalipun banyak orang yang menjual tahu isi tetapi isinya yang berbeda, Yang kedua adalah sangat mudah di pasarkan, modalnya sangat terjangkau, bahannya mudah didapatkan serta memiliki banyak manfaat. Yang ketiga adalah tahu isi ikan lele ini 
sangat unik dan memiliki rasa yang berbeda dengan yang lain. Dengan dasar inilah penulis ingin menawarkan usaha ini kepada masyarakat luas sehingga mereka dapat menikmatinya.

\section{BAHAN DAN GAMBARAN YANG DIGUNAKAN DALAM PRODUK}

Dalam produk ini kami beri nama "Tahu Isi Ikan Lele" Mengapa di beri nama Tahu isi Ikan lele karena isinya ikan lele, selain itu karena produk ini belum ada yang membuka usaha tahu isi ikan lele dan ini sangat unik.

\section{Komposis Bahan Dasar}

1. Kemiri 5 Butir

2. Bawang Putih 10 Siung

3. Bawang Merah 5 Butir

4. Ladaku/ Merica 2 Bungkus

5. Lombok Kecil merah 10 Biji

6. Garam /Ajinomoto secukupnya

7. Terigu $1,5 \mathrm{Kg}$ untuk 50 biji tahu

8. Royko

9. Air Secukupnya

10. Ikan Lele $1 \mathrm{~kg}$

11. Tahu 50 Biji

12. Toge secukupnya

Bahan utama yang digunakan dalam usaha ini sangat memiliki banyak manfaat bagi kita. Mari kita melihat manfaat dari bahan- bahan yang di gunakan dalam usaha ini: 


\section{Tahu}

Bahan utama dalam membuat tahu adalah kedelai. Selain bahan untuk pembuatan tahu, juga memiliki banyak manfaat seperti sebagai bahan pembuatan susu,dan lain-lain Tahu pertama kali muncul di Tiongkok sejak zaman Dinasti Han sekitar 2200 tahun lalu. Menurut Anggraini yang dikutip oleh Vidiawati bahwa penemu pertama tahu adalah adalah Liu An (Hanzi) yang merupakan seorang bangsawan, cucu dari Kaisar Han Gaozu, Liu Bang yang mendirikan Dinasti Han ${ }^{1}$

. Tahu dapat diolah dengan berbagai macam cara untuk dapat di nikmati oleh semua kalangan masyarakat luas.

"Kedelai yang dikenal sekarang termasuk dalam Famili Leguminosa Subfamili Papilionidae, Genus Glycine,dan spesies max, sehingga nama latinnya dikenal sebagai Glycine max. Kedelai merupakan tanaman penghasil protein yang paling murah di dunia. Di Indonesia Kedelai mempunyai kadar protein 30,53 sampai 44 persen" 2

Tahu isi ini, sangat banyak di gemari oleh masyarakat luas, sebagai makanan pengganti protein hewani untuk memenuhi kebutuhan gizi.

Pada tahu terdapat berbagai macam kandungan protein, lemak, atau zat gizi lain, seperti karbohidrat, kalori dan mineral, fosfor, vitamin B-komplek seperti thiamin, riboflavin, vitamin E, vitamin B12, kalium dan kalsium ( yang bermanfaat terbentuknya kerangka tulang). Dan paling penting dengan kandungan sekitar $80 \%$ asam lemak tak jenuh tahu tidak banyak mengandung kolesterol,sehingga sangat aman bagi kesehatan jantung. ${ }^{3}$

Di balik kelezatannya, tahu menyimpan kasiat medis tersendiri. Sebuah studi oleh tim medis dari Kanada membuktikan bahwa tahu dapat menurunkan kolesterol jahat dalam tubuh. ${ }^{4}$

Tahu isi yang sudah diolah yaitu dengan cara di goreng kita bisa isi apa saja di dalamnya. Melalui usaha ini penulis ingin mengisinya dengan ikan lele sehingga dapat

${ }^{1}$ Vidiawati, “Analisis Kandungan Formalin Pada Tahu Di Gampong Ujung Padang, Puloe Ie Dan Blok 10 Kecamatan Kuala Kabupaten Nagan Raya Tahun 2013” (Skripsi, Universitas Teuku Umar Meulaboh, 2014), 18.

${ }^{2}$ Eko Purwanto, Cara Pembuatan Tahu dan Manfaat Kedelai (Bekasi: Ganeca Exact, t.t.), 1,2.

${ }^{3}$ Bdk 19.

${ }^{4}$ Bdk 19. 
menabah protein, selain menambah kandungan protein juga bisa di jadikan lauk sebagai pauk sehari-hari

\section{Ikan Lele}

Ikan lele adalah salah satu ikan air tawar yang sangat muda di dapatkan. Ikan lele juga memiliki manfaat bagi kita yaitu dapat meningkatkan gizi bukan hanya pada orang dewasa tetapi juga dapat meningkatkan gizi bagi balita. "Daging ikan lele mengandung asam lemak omega-3 yang sangat dibutuhkan untuk membantu perkembangan sel otak pada anak dibawah usia 12 tahun sekaligus memelihara sel otak."

Pada daging ikan lele dapat membantu pertumbuhan sel otak pada anak-anak khusunya di bawah umur 12 tahun.

Dari hasil analisis dengan metode HPLC (high performance liquid chromatography) menunjukkan bahwa ikan lele mengandung asam lemak omega3 13,6 g/100 gr, asam lemak omega-6 22,2 gr/100gr dan asam lemak omega-9 19,5 gr/100gr. Kandungan tertinggi adalah asam lemak omega-6. Ini menunjukkan bahwa ikan lele dapat dimanfaatkan masyarakat untuk meningkatkan gizi balita sebagai pengganti ikan lainnya yang nilainya ekonomis lebih rendah dibandingkan dengan ikan salmon, tuna dll. ${ }^{6}$

Jadi, Ikan lele selain di jadikan lauk pauk juga dapat menamba gizi pada bayi. maka bisa juga di komsumsi oleh semua kalangan termasuk anak-anak, dan ini sangat bermanfaat dan membantu bagi pertumbuhan sel otak pada anak.

Adapun sumber bahan-bahan yang digunakan dalam usaha ini adalah kita dapat bekerja sama dengan pengusaha tahu goreng, pengusaha ikan lele, dan juga penjual rempa-rempa (bumbu-bumbu) yang bisa kita gunakan dalam usaha ini seperti, lombok,

5 Asfari Asfari dkk., "View of SOAL BAKAT (Selai Olahan Lele Banyak Khasiat)," 262, diakses 3 Maret 2020, http://journal.ummgl.ac.id/index.php/urecol/article/view/747/714.

${ }^{6}$ Nurasmi Nurasmi, Agus Purnama Sari, Dan Rusmiati Rusmiati, "Analisis Kandungan Asam Lemak Omega 3, Omega 6 Dan Omega 9 Dari Ikan Lele (Clarias Sp) Pada Peningkatan Nutrisi Balita," Journal Of Borneo Holistic Health 1, No. 1 (2018): 98. 
kemiri, bawang Putih, bawang merah, ladaku/ merica garam ,Ajinomoto, terigu, penyedap rasa.

\section{Analisa SWOT ${ }^{7}$}

Strenght (Kekuatan) Dalam produk ini memiliki gizi yang double, dari sari biji kedelai dan ikan yang penuh protein omega. Bisa dikonsumsi dengan nasi (menjadi lauk seharihari), dan juga dikonsumsi hampir sebagian masyarakat sekitar. Bahannya juga mudah didapatkan (tahu goreng dan ikan Lele). Tahu isi ini cocok bila dipadukan dengan nasi merah seperti produk Nameko (Nasi merah kotak-kotak). ${ }^{8}$ Teknik pembuatannya pun sangat mudah.. Selain itu harganya pun sangat terjangkau, sehingga semua kalangan dapat membelinya dan menikmatinya.

Weakness (Kelemahan) Produk ini tidak bisa disimpan terlalu lama karena tahu dan ikannya cepat busuk, selain itu sekalipun bisa di komsumsi oleh semua kalangan tetapi juga tidak bisa di komsumsi oleh orang-orang tertentu seperti orang-orang yang menderita penyakit asam urat dan juga alergi ikan lele.

Opportunity (Peluang) Dalam Produk ini sangat memiliki peluang yang besar karena belum terlalu ada saingan, selain itu juga sangat mudah di pasarkan, dan juga modalnya sangat terjangkau.

Threat (Ancaman) Selain memiliki peluang juga memiliki ancaman yaitu kemungkinan sangat mudah di tiru oleh orang lain. Ancaman lain juga bisa kurang dimiati oleh orang-orang tertentu.

\footnotetext{
${ }^{7}$ Hengki Wijaya, “Analisis SWOT Tentang Pembinaan Kesiswaan dan Pengembangan Program Pembinaan Siswa," 2018, https://www.researchgate.net/profile/Hengki_Wijaya3/publication/325493778_Analisis_SWOT_Tentang _Pembinaan_Kesiswaan_dan_Pengembangan_Program_Pembinaan_Siswa/links/5b113deaaca2723d9979 79ac/Analisis-SWOT-Tentang-Pembinaan-Kesiswaan-dan-Pengembangan-Program-PembinaanSiswa.pdf.

${ }^{8}$ Hengki Wijaya dan Tuflikha P. Putri, "KEWIRAUSAHAAN NAMEKO (NASI MERAH KOTAK-KOTAK) DALAM MENGGIATKAN PANGAN LOKAL YANG SEHAT” (Prosiding Seminar Nasional Pangan, Teknologi, dan Entrepreneurship, Makassar, Indonesia: Universitas Fajar Makassar, 2019), https://osf.io/vzd48.
} 


\section{METODE PELAKSANAAN}

\section{Cara Pembuatan}

Dalam membuat tahu isi ikan lele ini tidak berbeda jauh dengan tahu isi lainnya hanya saja isinya ikan lele. Adapun cara pembuatan "Tahu Isi Ikan Lele"adalah sebagai berikut:

Sediakan ikan lele yang sudah dibersikan kemudian di kukus sampai setengah matang, setelah itu di angkat dan bunang airnya. Tunggu sampai dinging. Setelah itu di pisahkan dangingnya dari tulang-tulangnya.

Siapkan tahu yang sudah di potong-potong kemudian di goreng sampai setengah masak

Siapkan bumbu yang sudah di haluskan kemudian ditumis dan masukan ikan lele yang sudah di pisahkan dari tulang-tulangnya, tumis sampai masak.

Kemudian tahu yang sudah di goreng di isi dengan ikan yang sudah di tumis. Siapkan loyang kemudian, masukan garam roiko, terigu, campur dengan air secukupnya, kemudian masukan tahu yang sudah di isi dengan ikan lele ,aduk sampai rata

Setelah itu kita goreng samapai masak, Kemudian angkat, tiriskan dan siap saji.

\section{Lokasi Penjualan}

Lokasi di mana penulis akan membuka usaha, yaitu di daerah perkotaan tempat penulis tinggal, selain itu bisa bekerja sama dengan penjual gorengan lainnya untuk bisa memasarkan produk ini. Dan juga penulis akan bekerja sama dengan Gojek Food, dan juga Grab Food, Sehingga pemasarannya sangat mudah di ketahui oleh masyarakat luas.

Selain itu strategi lain yang bisa dilakukan oleh penulis adalah mencari tempattempat yang ramai dan membuat gerobak gorengan tahu isi ikan lele agar pemasarannya lebih cepat tersalurkan dengan baik. 


\section{ANGGARAN DANA}

Anggaran dana ini mengutip contoh proposal pembuatan boneka lucu (Bolu). ${ }^{9}$ Selanjutnya formatnya disesuai dengan produk tahu isi Lele (TIsel) Dengan memperhatikan proses pengelolahan tahu isi ikan lele, maka dana awal digunakan dalam proses pembuatan produk ini adalah senialai Rp 112.600/ 1 kg Ikan lele Dengan Rincian sebagai berikut:

1. Kemiri 5 Butir

2. Bawang Putih 1Bungkul

3. Bawang Merah 5 Butir

4. Ladaku/ Merica 1 Bungkus $4 \mathrm{~g}$

5. Daun Bawang

6. Lombok Kecil merah 10 Biji

7. Garam /Ajinomoto secukupnya

8. Terigu $1,5 \mathrm{Kg}$ untuk 100 biji Tahu

9. Royko 1 bungkus

10. Ikan Lele $1 \mathrm{~kg}$

11. Tahu +_50 Biji

12. Minyak Bimoli

13. Gas

14. Ongkos Kerja

15. Biaya Transportasi

16. Sarung tangan

$\begin{array}{lr}\text { Rp } & 1.500,- \\ R p & 1.500,- \\ R p & 2.000,- \\ R p & 1.000,- \\ R p & 2.500,- \\ R p & 1.500,- \\ R & 100,- \\ R p & 3.500,- \\ R p & 500,- \\ R p & 20.000,- \\ R p & 16.000,- \\ R p & 20.000,- \\ R p & 10.000,- \\ R p & 25.000,- \\ R p & 5.000,- \\ R & 2500,- \\ R & \end{array}$

Jumlah Rp 112.600/ 1 kg Ikan Lele

9 Jonathan Matheus dkk., "Proposal Kegiatan Kreativitas Handmade BOLU (Boneka Lucu)," preprint (Open Science Framework, 30 Desember 2019), https://doi.org/10.31219/osf.io/nwdap. 
Jadi dalam jumlah $3 \mathrm{Kg}$ Ikan lele dapat menghasilkan 200 biji tahu isi. Maka hasilnya adalah $\operatorname{Rp} 112,600$ x 3 = Rp 337800,-

Hasil penjualan dari 200 biji tahu isi dengan harga Rp 2000/ Biji = Rp 400.000,-

\section{KEPUSTAKAAN}

Asfari, Asfari, Annida Nurul Arafati, Tri Mugiarti Tri Mugiarti, Siti Li Cholisna, dan Wahisah Wahisah. "View of SOAL BAKAT (Selai Olahan Lele Banyak Khasiat)." Diakses 3 Maret 2020.

http://journal.ummgl.ac.id/index.php/urecol/article/view/747/714.

Matheus, Jonathan, Hengki Wijaya, Grace Irene Kalamu, dan Josevina Marisa Penfani. "Proposal Kegiatan Kreativitas Handmade BOLU (Boneka Lucu)." Preprint. Open Science Framework, 30 Desember 2019. https://doi.org/10.31219/osf.io/nwdap.

Nurasmi, Nurasmi, Agus Purnama Sari, dan Rusmiati Rusmiati. “ANALISIS KANDUNGAN ASAM LEMAK OMEGA 3, OMEGA 6 DAN OMEGA 9 DARI IKAN LELE (Clarias sp) PADA PENINGKATAN NUTRISI BALITA.” Journal of Borneo Holistic Health 1, no. 1 (2018): 96-100.

Purwanto, Eko. Cara Pembuatan Tahu dan Manfaat Kedelai. Bekasi: Ganeca Exact, t.t.

Vidiawati. "ANALISIS KANDUNGAN FORMALIN PADA TAHU DI GAMPONG UJUNG PADANG, PULOE IE DAN BLOK 10 KECAMATAN KUALA KABUPATEN NAGAN RAYA TAHUN 2013.” Skripsi, Universitas Teuku Umar Meulaboh, 2014. http://utu.ac.id/.

Wijaya, Hengki. “Analisis SWOT Tentang Pembinaan Kesiswaan dan Pengembangan Program Pembinaan Siswa," 2018. https://www.researchgate.net/profile/Hengki_Wijaya3/publication/325493778_ Analisis_SWOT_Tentang_Pembinaan_Kesiswaan_dan_Pengembangan_Progra m_Pembinaan_Siswa/links/5b113deaaca2723d997979ac/Analisis-SWOTTentang-Pembinaan-Kesiswaan-dan-Pengembangan-Program-PembinaanSiswa.pdf.

Wijaya, Hengki, dan Tuflikha P. Putri. "KEWIRAUSAHAAN NAMEKO (NASI MERAH KOTAK-KOTAK) DALAM MENGGIATKAN PANGAN LOKAL YANG SEHAT.” Makassar, Indonesia: Universitas Fajar Makassar, 2019. https://osf.io/vzd48. 